\title{
Thinking Managers can Enhance Their Performance through Psychological and Spiritual Dynamic Attitudes within Learning Organizations
}

\author{
Linah Askari
}

\begin{abstract}
Building of Learning Organizations requires the enhancement of Psychological and Spiritual Dynamic Attitudes of the Managers. Author's Learning Model 2012 reveals that 'Learning as a complex process starts from the functioning of an individual's interconnected eight senses, leads to eight types of perceptual learning. These perceptual learnings provide formation of attitudes to fulfill the needs for seven major value systems'. These attitudes of the managers whether dynamic or dysfunctional, pave the path of success or failure respectively, for the performance within an Organization. This research tends to investigate whether Organizations support and use "learning" at an individual, team and organizational level to improve their performance. And that improvement in their performance has direct relationship with psychological and spiritual dynamic attitudes of their Managers. Results showed that Cronbach's Alpha $=.938$ for all six items. Significant 2tailed Correlations at the 0.01 level for DAS Psychological at Individual organizational level $=.719 * *$ and Team level $=.782 * *$ at Organizational level $=.779 * *$ \& at Organizational Performance level $=.812 * *$ whereas for DAS Spiritual at Individual level $=.610^{* *}$ at Team level $=.713 * *$ at Organizational level $=.665 * *$ at Organizational Performance level $=.714 * *$.
\end{abstract}

Index Terms-Dynamic attitudes, learning organizations, psychological and spiritual, thinking managers.

\section{INTRODUCTION}

As a substitute to achieve targets and goals, in the present era the thinking managers emphasize upon the utilization of the best strategies to perform the tasks, more willingly than to accomplish the results. Furthermore, thinking managers analyze the situation through disciplined intuitive intelligence within their organizational decision making to integrate their action plan to diagnose the real problem and implement the solution [1]. As quoted by Rene Descartes, "It is not enough to have a good mind. The main thing is to use it well".

Whether managers are optimistic (having dynamic attitudes as a way of looking at the world) or pessimistic (having dysfunctional attitudes as they perceive their environment affects the company's bottom line. Optimistic organizations become successful and powerful whereas pessimistic organizations remain helpless. Generally people are not born pessimists or optimists but their experiences enable them to learn such behaviors from people within their environment or the ones they make their role models [2].

Manuscript received August 7, 2013; revised November 21, 2013.

Linah Askari is with the Institute of Business Management, Korangi Creek, Karachi, Pakistan (e-mail: dr.linah@iobm.edu.pk).
Every individual performs by perceptually learning through the eight senses which mature to form the attitudes and become absorbed within the soul. Learning provides formation of attitudes to fulfill needs with seven major value systems such as; approval, love, achievement, perfection, entitlement, omnipotence and autonomy.

See Fig. 1, attitude reflects through the face and eyes, and the learning's embedded within the soul enable the human to function accordingly; positive attitudes lead to positive, dynamic, functional and adaptive behaviors, whereas negative attitudes lead to negative, dysfunctional and maladaptive behaviors. All the six dimensional negative behaviors can be changed by will power, acceptance, knowledge and wisdom towards the positive behaviors.

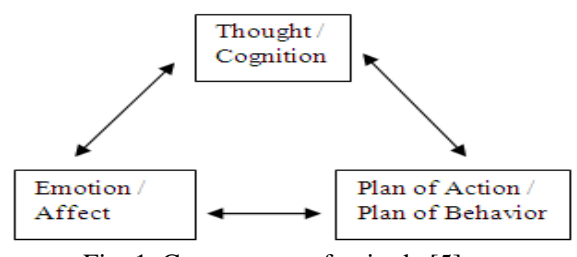

Fig. 1. Components of attitude [5]

In fact all the six dimensions are interconnected to each other, but specifically the psychological and spiritual attitudes whether positive or negative, are more empowered than the others to influence the personality of an individual human being. These eight senses receive the messages within their domains from the environment, and transforms into their respective perceptions in four steps; 1) Reception when the stimulus molecules attach to receptors, 2) Transduction - when the receptors convert the energy of chemical reaction into action potentials, 3) Coding - when the spatial and temporal pattern of nerve impulses represents a stimulus in a meaningful way, and 4) Decoding - when the meaning of spatial and temporal patterns of nerve impulses are expressed and explained to the heart and mind.

Suppose for example; if the Manager decides to escape from 'obesity' and 'procrastination' by being careless for his health and time management, he surely has the mindset of 'flight from professional responsibilities' which may hinder his / her professional performance. The individual needs to utilize all the eight senses to understand and form perceptions about health, the food to be eaten and time management. The Manager has been confirmed in all areas concerning 'health and time management' that he/she does not have a smart 'vision or image' of self, does not hear good comments about self, swelling of the body weakens the kinaesthetic sense, neurohormonal imbalance is experienced which evokes the unbearable odor of the sweat, also mentioned in the 
sense-imagery exercises by [3]. Furthermore, emotional relationships with the boss and subordinates are disturbed and form irrational perceptions to predict undesirable circumstances.

Hence, the spirit performs with heaviness and lethargy associated with intense negative energy, and a feeling of 'doing something wrong' persists (as denoted in spiritual cleansing by [4]. Similarly, the eight perceptions about 'food and punctuality' would be; presentable, heard good remarks about it, delicious and satisfying, smell that would make your mouth watery and sigh of relief, some emotional attachment providing reasons to believe and predict the food/punctuality to give pleasure and satisfaction, and spiritually your conscience allows to eat/perform the task.

It is imperative for the manager to immediately consult about his/her maladaptive behavior as the success of an organization depends upon utilization of every hour for the enhancement of the organization at an 'Individual level', 'Team level', 'Organizational level' and ultimately for the 'Organizational Performance level'. If the manager understands the process of psyche' discipline (See Fig. 2), it would be much easier, at any age and stage to overcome their problems, find definite solutions for personal insight and professional drawbacks. Furthermore the manager would be able to mentor his subordinates, team members, family members and change the dysfunctional attitudes into dynamic attitudes.

In the process of psyche' discipline, the manager's perceptual learning (all eight of them) would now mature to form six dimensional 'Attitudes'. The three components of attitude are; 1) Cognition/Thought, 2) Emotion/Affect and 3) Plan of Action/Plan of Behavior (also proposed with slight difference by [6], [7]. These six dimensional attitudes would be 'absorbed within the soul' and are categorized as 'Dynamic' (positive, functional, effortful) and 'Dysfunctional' (negative, malfunctioning carefree). "The formation of 'Attitudes' then enables a person to 'Act or Behave' with respect to its positivity or negativity", hence provides evidence that 'All Behaviors are from Attitudes', as proposed by [8]-[10].

The factors guiding these attitudes to behave or perform in a certain way are; motivational level, personality traits, subliminal persuasion, level of interest, level of intellect and mood swings of the individual. At the completion of the process of psyche' discipline, the manager would have dynamic or dysfunctional attitudes within six dimensions to care or not to care for his/her 'health and punctuality' and behave in accordance to change or resist the habit for Unhealthy Eating and procrastination.

\section{A. Examples of Dynamic Attitudes within Six Dimensions Are}

\section{1) Physiological}

- There is a great influence of our physiological health on our mental capacity and life achievements.

- A person who takes daily care of balanced food, oxygen and water regulation is an admirable person.

\section{2) Psychological}

- To be appreciated morally and become a worthwhile person, one must help only those who ask. Never be a 'door mat'.

- Making mistakes is fine because I can learn from them. It is normal to make mistakes and learn from personal experiences.

THE SOULSTNCHEONIZZS ALL RGHT SDNE OBCANS WHCA FUNCTON IN SINEACY, TO ENABUELEARNDNG TOWARDS PERFOBMANCE

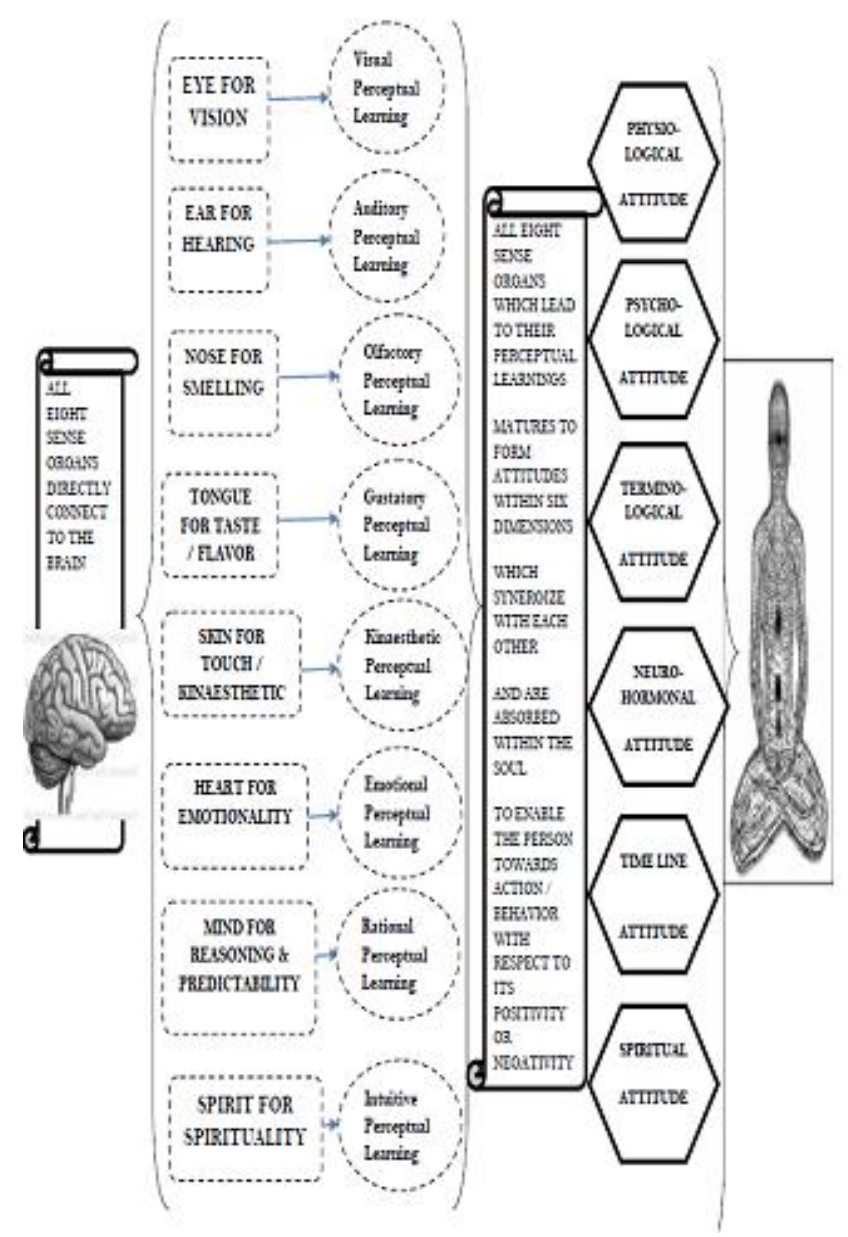

Fig. 2. The process of human psyche' discipline [author 2012].

\section{3) Terminological}

- It is in my hand to keep control over my spoken language and choose the effective words for communicating with others.

- If a person is selective for terminology to express at every step, it is a sign of one's strength.

4) Time line

- If 'Time is money \& Health is wealth', then it means that 'Time Management will keep you healthy and wealthy.'

- If a person's time management is good, he/she will perform well and achieve better, by keeping oneself in a relaxed manner.

\section{5) Neurohormonal}

- Balanced Neuro-hormonal regulation can enhance the performance level of an individual to improve the quality of life.

- My happiness and relaxed state depends more on my neuro-hormonal balance, which is under my own control, through massages. 


\section{6) Spiritual}

- My own opinion of myself in the eyes of Allah SWT (The Creator) is more important, than other's opinion of me as a human being.

- "Honesty pays at the right time," because Allah SWT's (The Creator's) justice is perfect, life is 'Makafat-e-Amal', what we give to others, and ourselves, we receive the same.

\section{B. Examples of Dysfunctional Attitudes within Six} Dimensions Are

\section{1) Physiological}

- Deep Breathing is only required when a person wants to meditate or sleep, otherwise it is useless.

- Our physiological tendencies are inherited, whatever care we take, it will not affect at all and we'll remain the same.

\section{2) Psychological}

- If one becomes isolated from the people within the environment, it will lead to unhappiness and depression, so we need to keep them always happy from our side.

- An individual's self-esteem will be graded higher depending upon the thoughts of other people.

\section{3) Terminological}

- All the time, I must speak in a polite, soft, encouraging and reinforcing manner or people will not respect me.

- I am frank and outspoken, so even if I use negative terminology for anyone, I am justified in doing so.

\section{4) Time line}

- Time has to pass anyway, we cannot hold time, and the fate will give you what's written for you, so don't worry about time.

- One must spent most of the time in enjoying life, as we get the life just once, and there is very little time in our life.

\section{5) Neurohormonal}

- A person will have to take medicines related to brain activity to change or regulate the neuro-hormonal balance.

- There is no connection at all between the thought process and a neuro-hormonal response.

\section{6) Spiritual}

- Only prophets can communicate with Allah SWT (The Creator) and an ordinary person like me, cannot. Not even in dreams or Intuition.

- Allah SWT (The Divine Being, The Creator) has all the powers, and one cannot do anything to change one's fate or life. So we have to live the way it comes to us. Destiny is written and is unchanged.

Generally, it is the dysfunctional attitude, which may be coined as, 'the food is not enough and I might remain hungry', or 'there is lots of time and the work gets completed anyway', which misguides a person to eat more and more and still the feeling of hunger remains, that something was lacking or the person becomes more and more lazy towards performance. After changing this negative attitude towards the positive one now the manager has learnt to care for his / her health or manage time, and forms a dynamic attitude. Eating healthier means to drink one glass of water first, then as soon as one starts eating, communicates the attitude to oneself inwardly that 'my stomach is nearly full and I would just taste a few bites'. This dynamic attitude will provide 'operant conditioning' for the individual to eat less and still become satisfied. Similarly, prioritizing tasks and imagining to work upon the next step with self communication would enhance the speed of task accomplishment and enable punctuality.

Insight about the cause, need, type and the process of learning is essential for the managers within the learning organizations. So that they can consciously work out on what is beneficial to learn, which they can regularly keep installing within them, and what is harmful for their learning, which they must keep regularly deleting or uninstalling from their lives.

\section{Methodology}

Stratified random sampling technique was conducted upon the sample size of 75 managers from multinational and national organizations in Karachi. The online questionnaires administered were a) Dynamic Attitude Scale-Six Dimensions, Modified [11]. Available: (http://www.scribd.com/share/upload/106778062/1b6n03ys e6fqccm71rlf) and b) Dimensions of the Learning Organization Questionnaire [12]. Available: (http://www.partnersforlearning.com/questions2.asp). Data were statistically analyzed through SPSS version 17 for compilation of the results.

\section{LITERATURE REVIEW}

Comparison for predictors of job satisfaction and success of learning organizations was made across the Asian countries like Japan, China and Malaysia. The sample size for the survey was 600 managers of Japanese firm AEON across Asia. Learning enhances the human resource development and management worldwide. Therefore, employee adaptation was imperative to the cultural environment of the participating organization. The study reveals that Japanese managers learned through reflecting the feelings; Chinese managers learned through reflecting the thoughts; and Malaysian managers learned through acting upon their thought processes. Chinese managers were more balanced learners as compared to Malaysian managers, whereas Japanese managers evidenced the most specialized learning orientation [13].

Globalization in terms of technology and structure, makes learning organizations more homogenous, employees have unique behavior as per their values, entrenched within cultural values learnt from ethnic and national groups [14]. Innumerable administrative competencies which are rooted culturally such as specific communication patterns for exchange of ideas [15], Leadership development and progression processes [16], and approaches for the Negotiation tactics [14], [17].

The learning styles of managers to inculcate these competencies, is of interest to analyze put into practice within the HRM Internationally [18]. For practices in human resource management, learning must be an obligatory 
activity for individuals to utilize intuitive power to create, judge and obtain knowledge to use and put it into practice for the enhancement of their lives [19].

According to [20], the Experiential Learning Theory by [19] exerts enormous influence upon education and management learning strategies. The researchers [21] emphasize the importance of this theory in the Schools of Business. The researchers [22] highlight its importance in communities and [18] accentuate the utilization of this theory in cross - cultural studies. Hence, the Experiential Learning Theory (ELT) contemplates upon the vitality of distinct human experiences as the learning enterprise and emphasizes the function of tacit knowledge which catalyzes the learning processes of an individual [19], [23]. The experiential learning model as proposed by [19], encompasses an individual's total experiences within the following four steps providing the vicious cycle of learning, such as; when the people reflect through (RO) reflective observation, on the tacit experience known as (CE) concrete experience, then this experience transforms into (AC) abstract conceptualization or abstract knowledge, and subsequently, this knowledge becomes a tested experience by performing or taking action as (AE) active experimentation, which sequentially leads to a new experience [19].

\section{HYPOTHESES AND STATISTICAL RESUlTS}

\section{A. Hypothesis 1}

Psychological Dynamic Attitudes of Thinking Managers have positive correlation with their Learning Org.; 1) on Individual, 2) Team and 3) Org. levels. (Higher the score on Psychological DA of Thinking Managers Higher will be the total score for Learning Org. on each level, and Vice Versa). This hypothesis was Accepted; Correlations are marked at the significance level $p=0.01$ ( 2 tailed); for Psychological DA at Individual level $=.719 * *$ at Team level $=.782 * *$ and at Organization level $=.779 * *$.

\section{B. Hypothesis 2}

Spiritual Dynamic Attitudes of Thinking Managers have positive correlation with their Learning Organization; 1) on Individual, 2) Team and 3) Org. levels. (Higher the score on Spiritual DA of Thinking Managers Higher will be the total score for Learning Org. on each level, and Vice Versa). This hypothesis was Accepted; Correlations are marked at the signif. level $p=0.01$ (2-tailed); for Spiritual DA at Individual level $=.610^{* *}$ at Team level=.713** and at Org. level $=.665^{* *}$.

\section{Hypothesis 3}

Psychological Dynamic Attitudes of Thinking Managers have positive correlation with Org. Performance level. (Higher the score on Psychological DA of Thinking Managers Higher will be the score for Org. Performance level, and Vice Versa). This hypothesis was Accepted; Correlations are marked at the significance level $p=0.01$ (2-tailed); for Psychological DA at Org. Performance level $=.812 * *$.

\section{Hypothesis 4}

Spiritual Dynamic Attitudes of Thinking Managers have positive correlation with their Org. Performance level. (Higher the score on Spiritual DA of Thinking Managers Higher will be the score for Org. Performance level, and Vice Versa). This hypothesis was Accepted; Correlations are marked at the significance level $p=0.01$ (2-tailed) and for Spiritual Dynamic Attitude at Org. Perf. level=.714**.

\section{E. Hypothesis 5}

Psychological Dynamic Attitudes of Thinking Managers have more positive correlation with Org. Perf. level as compared to their Spiritual DA. This hypothesis was accepted with a negligible difference; Correlations are marked at the significance level $p=0.01$ (2-tailed); for Psychological DA at Org. Performance level $=.812 * *$ whereas for Spiritual DA at Org. Performance level=.714**.

\section{F. Tables and Graphs}

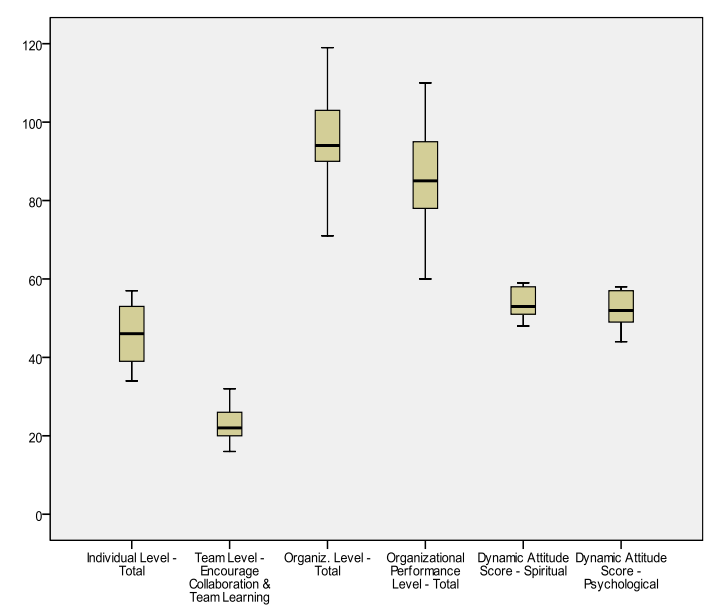

Graph 1. Boxplots of psychological and spiritual dynamic attitudes for individual, team and organizational levels

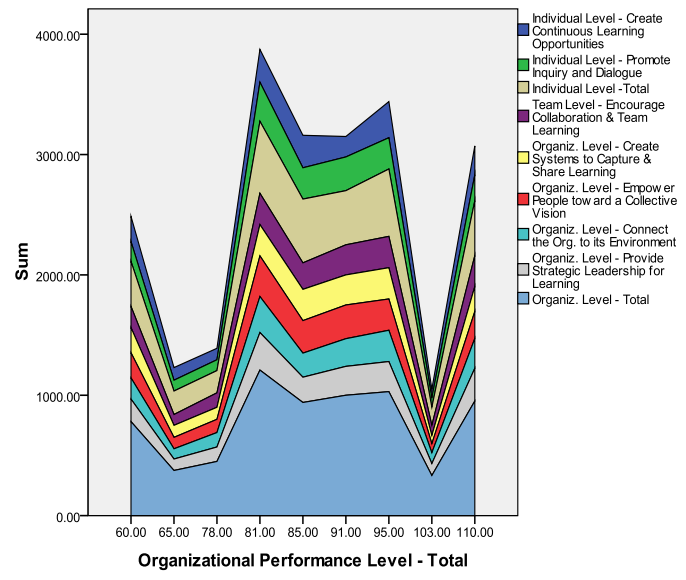

Graph 2. Sum of psychological and spiritual dynamic attitudes for individual, team and organizational levels vs. organizational performance level.

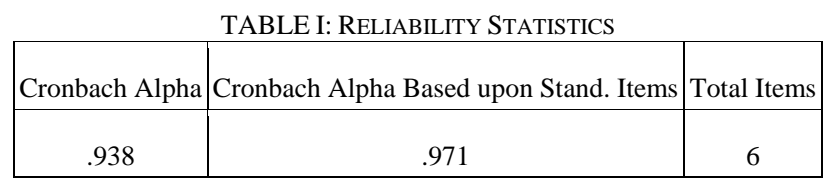

TABLE II: LINEAR REGRESSION MODEL SUMMARY - PSYCHOLOGICAL DYNAMIC ATTITUDES AT INDIVIDUAL LEVEL

\begin{tabular}{|c|c|c|c|c|}
\hline Model Fit & R value & $\begin{array}{c}\text { R square } \\
\text { value }\end{array}$ & $\begin{array}{c}\text { Estimated } \\
\text { Std. error }\end{array}$ & $\begin{array}{c}\text { Durbin-Watson } \\
\text { Score }\end{array}$ \\
\hline One & .992 & .985 & 5.82893 & 2.605 \\
\hline
\end{tabular}


TABLE III: PEARSON CORRELATION COEFFICIENTS

\begin{tabular}{|c|c|c|c|c|c|c|}
\hline & $\begin{array}{c}\text { Individua } \\
1 \text { Level } \\
\text {-Total }\end{array}$ & $\begin{array}{c}\text { Team } \\
\text { Level } \\
- \\
\text { Total }\end{array}$ & \begin{tabular}{|c} 
Org. \\
Level \\
- \\
Total
\end{tabular} & $\begin{array}{c}\text { Organizational } \\
\text { Performance } \\
\text { Level - Total }\end{array}$ & $\begin{array}{l}\text { Dynamic } \\
\text { Attitude } \\
\text { score - } \\
\text { Spiritual }\end{array}$ & $\begin{array}{c}\text { Dynamic } \\
\text { Attitude Score } \\
\text {-Psychological }\end{array}$ \\
\hline $\begin{array}{l}\text { Ind. } \\
\text { L. T. }\end{array}$ & 1 & $.761^{* *}$ & $.852^{\text {*** }}$ & $.869^{* *}$ & $.610^{* *}$ & $.719^{* *}$ \\
\hline $\begin{array}{l}\text { Team } \\
\text { L. T }\end{array}$ & $.761^{* *}$ & 1 & $.956^{* * *}$ & $.961^{* *}$ & $.713^{* *}$ & $.782^{* *}$ \\
\hline $\begin{array}{l}\text { Org. } \\
\text { L. T }\end{array}$ & $.852^{* *}$ & $.956^{* *}$ & 1 & $.997^{\text {** }}$ & $.665^{* *}$ & $.779^{* * *}$ \\
\hline $\begin{array}{l}\text { Org. } \\
\text { Perf. }\end{array}$ & $.869^{* *}$ & $.961^{* *}$ & $.997^{* *}$ & 1 & $.714^{* *}$ & $.812^{* *}$ \\
\hline $\begin{array}{l}\text { DAS } \\
\text { - Spir }\end{array}$ & $.610^{* *}$ & $.713^{* *}$ & $.665^{* *}$ & $.714^{* *}$ & 1 & $.869^{* *}$ \\
\hline $\begin{array}{l}\text { DAS } \\
\text {-Psyc }\end{array}$ & $.719^{* *}$ & $.782^{* *}$ & $.779^{* *}$ & $.812^{* *}$ & $.869^{* *}$ & 1 \\
\hline & orrelation & is sign & $\begin{array}{l}\text { hificant } \\
\text { Signific }\end{array}$ & $\begin{array}{l}\text { at the } 0.01 \text { level } \\
\text { cance (2-tailed). }\end{array}$ & Pearson & Correlation, \\
\hline
\end{tabular}

TABLE IV: LINEAR REGRESSION MODEL SUMMARY-SPIRITUAL DYNAMIC ATTITUDES AT INDIVIDUAL LEVEL

\begin{tabular}{|c|c|c|c|c|}
\hline Model Fit & R value & $\begin{array}{c}\text { R square } \\
\text { value }\end{array}$ & $\begin{array}{c}\text { Estimated } \\
\text { Std. error }\end{array}$ & $\begin{array}{c}\text { Durbin-Watson } \\
\text { Score }\end{array}$ \\
\hline One & .991 & .981 & 6.52521 & 2.589 \\
\hline
\end{tabular}

TABLE V: LINEAR REGRESSION MODEL SUMMARY-PSYCHOLOGICAL DYNAMIC ATTITUDES AT TEAM LEVEL

\begin{tabular}{|c|c|c|c|c|}
\hline Model Fit & R value & $\begin{array}{c}\text { R square } \\
\text { value }\end{array}$ & $\begin{array}{c}\text { Estimated } \\
\text { Std. error }\end{array}$ & $\begin{array}{c}\text { Durbin-Watson } \\
\text { Score }\end{array}$ \\
\hline One & .989 & .979 & 3.41787 & 2.495 \\
\hline
\end{tabular}

TABLE VI: LINEAR REGRESSION MODEL SUMMARY-SPIRITUAL DYNAMIC ATTITUDES AT TEAM LEVEL

\begin{tabular}{|c|c|c|c|c|}
\hline Model Fit & R value & $\begin{array}{c}\text { R square } \\
\text { value }\end{array}$ & $\begin{array}{c}\text { Estimated } \\
\text { Std. error }\end{array}$ & $\begin{array}{c}\text { Durbin-Watson } \\
\text { Score }\end{array}$ \\
\hline One & .987 & .975 & 3.74448 & 2.688 \\
\hline
\end{tabular}

TABLE VII: LINEAR REGRESSION MODEL SUMMARY-PSYCHOLOGICAL DYNAMIC ATTITUDES AT ORGANIZATIONAL LEVEL

\begin{tabular}{|c|c|c|c|c|}
\hline Model Fit & R value & $\begin{array}{c}\text { R square } \\
\text { value }\end{array}$ & $\begin{array}{c}\text { Estimated } \\
\text { Std. error }\end{array}$ & $\begin{array}{c}\text { Durbin-Watson } \\
\text { Score }\end{array}$ \\
\hline One & .995 & .991 & 9.33536 & 2.738 \\
\hline
\end{tabular}

TABLE VIII: LINEAR REGRESSION MODEL SUMMARY-SPIRITUAL DYNAMIC ATTITUDES AT ORGANIZATIONAL LEVEL

\begin{tabular}{|c|c|c|c|c|}
\hline Model Fit & R value & $\begin{array}{c}\text { R square } \\
\text { value }\end{array}$ & $\begin{array}{c}\text { Estimated } \\
\text { Std. error }\end{array}$ & $\begin{array}{c}\text { Durbin-Watson } \\
\text { Score }\end{array}$ \\
\hline One & .994 & .987 & 10.89592 & 2.824 \\
\hline
\end{tabular}

TABLE IX: LINEAR REGRESSION MODEL SUMMARY-PSYCHOLOGICAL DYNAMIC ATTITUDES AT ORGANIZATIONAL PERFORMANCE LEVEL

\begin{tabular}{|c|c|c|c|c|}
\hline Model Fit & $R$ value & $\begin{array}{l}\text { R square } \\
\text { value }\end{array}$ & $\begin{array}{l}\text { Estimated } \\
\text { Std. error }\end{array}$ & $\begin{array}{l}\text { Durbin-Watson } \\
\text { Score }\end{array}$ \\
\hline One & .993 & .986 & 10.07467 & 2.796 \\
\hline
\end{tabular}

TABLE X: LINEAR REGRESSION MODEL SUMMARY-SPIRITUAL DYNAMIC ATTITUDES AT ORGANIZATIONAL PERFORMANCE LEVEL

\begin{tabular}{|c|c|c|c|c|}
\hline Model Fit & R value & $\begin{array}{c}\text { R square } \\
\text { value }\end{array}$ & $\begin{array}{c}\text { Estimated } \\
\text { Std. error }\end{array}$ & $\begin{array}{c}\text { Durbin-Watson } \\
\text { Score }\end{array}$ \\
\hline One & .991 & .982 & 11.52859 & 2.889 \\
\hline
\end{tabular}

\section{DISCUSSION AND RECOMMENDATIONS}

The results' report of the organizations, received from the online survey, reveals that to create the continuous learning opportunities within the individual level of the Learning Organizations, they need to follow the following steps:

\section{A. To Perform Experiments and Start Taking Risks}

- By focusing primarily on individual success and addressing critical problems

- Avoid discussions about past mistakes or searching to blame someone

- Develop leadership strategies to discuss the mistakes of employees as 'a learning opportunity'

- Discuss and Learn from errors through holding meetings in public

- Hold 'Learning Reviews' after the action have occurred

B. Systematically Identify the Current Necessary Skill Base for Future Business Endeavors

- Provide competency assessment strategies for identification of skills required in future

- Assess the present skills and competencies of workforce available

- Analyze the organizational work tasks and projects for implications in future

- Include 'Training Program' or 'Focused Hiring program' to concentrate on necessity for future

- Inculcate Psychological and Spiritual Dynamic Attitudes for progression at every step

C. Discourage Individual Success if Achieved at the Cost of Knowledge-Sharing

- Build the 'job systems' where learning can be shared with each other

- Provide strategies to include rewards and recognition when transference of learning occurs

- Appreciate coaching and mentoring habits of employees

- Award the teams when they acquire achievements for the organization

\section{Provide Easily Accessible Learning Resources for Employees}

- $\quad$ Create funds for personal development to be controlled by employees

- $\quad$ Provide easily accessible electronic directory and library resources

- Provide course of action for managers to straightforwardly sanction the activities for learning

\section{E. Integrate the Learning Opportunities into Organizational Work Procedures}

- Timely appreciate the accomplishment of the required tasks.

- Time consumed for learning may always be rewarded 
and encouraged

- Systems supporting electronic performance may be integrated for learning at workplace

- Minimum requirement for training and development may be proposed as 40 hours within a year

- Seminars for 'Virtual learning' may be planned

- 'Expression and Reflection' of the learning acquired may be designed within work procedures

F. Acknowledge the Challenges and Problems within the Environment through Collection of Correct Data

- Methods need to be emphasized for collection of information on outcomes whether they are unanticipated or anticipated

- Introduce strategies to gather accurate facts and implement the learning acquired from the problems and challenges

- Structure the 'Trial and Error' technique into the actual work process

- Reinforce the 'Action Learning Teams' as per their personal motivation

\section{G. Adequately Persuade the Learning Opportunities for} Employees

- Bond these chances given for learning with the tangible and non-tangible incentives

- 'Employee Learning Time' may be taken as a prospect to organizational achievement

- Suitable rewards be provided for learning, which would enhance the organizational brand name

- Salary and rank may be increased with the enhancement in knowledge or educational level

- Provide strategies to develop individuals toward self actualization and celebrate their accomplishments

Furthermore, the results' report of the organizations, received from the online survey, reveals that to promote inquiry and dialogue within the individual level of the Learning Organizations, they need to follow the following steps:

\section{H. Articulate the 'Open Exchange of Ideas' and Convey Organizational Expectations and Norms}

- Feedback has to be mandatory in understanding the expectations and standards, as well as for the change in employee behavior to meet organizational expectations

- Provide strategies to promote such skills and the 'Feedback Culture'

- Feedback and Reflection of employee behavior may be planned within the concluding sessions

- Electronic Feedback is far more effective among employees

- Arouse curiosity through the 'Message' and create interest for 'Thinking Managers'

\section{Communicate the 'Innovative Idea' with Impact}

- Encourage the discussion of 'Conflicting Perspectives'

- Develop 'Listening Cultures' to benefit from 'Diverse Innovative Viewpoints'

- Provide training for teams in 'Dialogue', 'Skillful discussion', and 'Active listening'

- Induct conferences to promote 'Brainstorming activities'

\section{J. Excellence and Communication of Ideas Be}

Emphasized Rather Than Emphasis on Status and Hierarchy

- Encourage challenging tasks and terminate the value for being a 'Yes-Boss' type of employee

- Leaders may adapt 'Inclusive Decision Making Style'

- Systems may be introduced to provide 'Anonymous Suggestions'

- Leaders may be encouraged to model 'Collegial relationships' and 'Respectful Climate'

- 'Leader's Repertoire' may include enthusiasm and willingness to take risks

- Persuade conversations that inquire for deeper understanding and invite organizational challenges

- Avoid 'False Politeness' strategies of 'Conformity and 'Saving Face'

\section{K. Build 'Trust' and Delete the 'Culture of Fear'}

- Include strategies for openly sharing the rationale behind the most intricate decisions

- Enhance 'Team Building' and set norms for 'Trustworthy Promising Behavior'

Likewise, the results' report of the organizations, received from the online survey, reveals that to encourage collaboration and team learning within the group or team level of the Learning Organizations, they need to follow the following steps:

\section{Expand and Provide Freedom for Teams to Enhance} 'Mandate Rethinking' Procedures

- Avoid ideas which explore fear within employees to keep them 'Task Oriented'

- $\quad$ Set SMART (specific, measurable, achievable, relevant and time-bound) goals for the team to produce results

- Long-term team effectiveness depends upon written, accountable and clear objectives

- Consistent Communication' as a trait leads to successful teamwork

M. Inculcate 'Assertiveness' in the Organizational Culture to Prevent 'Domination or Seniority Influence'

- Rotate the 'Group Roles' to provide a chance for each member to develop leadership skills

- Ensure the awareness of all team members whenever a process or procedure is documented

- Identification of 'Role and Expertise' needed within the group be made essential in developing the 'Staffing' procedures on the basis of 'organizational plan' and not 'for personal favors'

N. Develop 'Three Folds' Relationships' within the

Organization to Enhance Productive Performance

- For inducing 'Group Membership', include diverse perspectives and values to ensure vigorous ideas and healthy discussions

- Evoke 'team growth' and develop 'workplace relationships' by planning activities for 'Team Building' which are cost effective and regularly monitored by the administration

- 'Stable Emotional Relationship' provides self-control, empowerment, confidence and mastery in dealing effectively with unforeseen circumstances

- 'Higher Mental Relationship' (the rational, logical, 
comparative, temporal and conditional) provides higher order dealing capability with abstractness and creativity

- 'Higher Spiritual Relationship' provides the effective management of risks in business through utilizing the powers of 'Intuitive Intelligence' and enhancing organizational reputation

\section{O. Indoctrinate the 'Devil's Advocate' Technique within the 'Learning Organization'}

- Provide 'Group activities' focused on questioning to probe the speculations and extract divergent viewpoints

- Formulate goals and strategies in which employees re-evaluate their stances, evading the mental framework which fasten them with the past strategies

\section{P. Celebrate the Accomplishments of Team Members on a Regular Basis, to Avoid 'Burnouts'}

- Psychological counseling for employees enable them to gain insight about their past, present and future mental states, and to acquire self control for progress

- Regular provision of reinforcements can guard the motivational level of employees towards the highest

\section{ACKNOWLEDGMENT}

The Author thanks Allawh Almighty for support at every step, and extend heartfelt gratitude to the following personnel who have made the completion of this research possible; the managers of the organizations participating in the study, the administration of Institute of Business Management, the cooperation of students of Practicum course and instigation by my colleague Mr. Asad Shahzad to probe into the topic of psyche' as soul, and its relationship within the study of psychology.

\section{REFERENCES}

[1] D. J. Isenberg. (Nov. 1984). How senior managers think. Harvard Business Review. [Online]. Available: http://hbr.org/1984/11/how-senior-managers-think/ar/1

[2] C. Brandson. (March 1, 1998). Management Attitudes Affect Productivity. [Online]. Available: http://trailerbodybuilders.com/mag/trucks_management_attitudes_affe $\mathrm{ct} /$.

[3] M. R. Hathaway. (July 2012). Sense-Imagery Exercises. [Online] Available:

http://www.netplaces.com/psychic/psychic-development-training/sens e-imagery-exercises.htm.

[4] M. E. Gibson and K. H. Gibson. (July 2012). Spiritual Cleansing. [Online]. Available: http://www.tybro.com/html/spiritual_cleansing.html.

[5] L. Askari, "Mother's Dysfunctional Attitude: Is She Responsible for My Emotional State in Adulthood?" in A. V. Akademikerverlag, GmbH \& Co. KG, Saarbrücken, Germany: LAP Lambert Academic Publishing, ch. Introduction, pp. 2-3, 2013.

[6] D. G. Myers. (2008). Social Psychology. [Online]. pp. 36. Available: highered.mcgraw-hill.com/sites/0073531898/information_center_vie w0 / http://www.nd.edu/ rwilliam/xsoc530/attitudes.html

[7] T. Kamradt and B. Kamradt, "Structured design for attitudinal instruction," in C. M. Reigeluth (Eds.), Instructional-Design Theory and Models: A New Paradigm of Instructional Theory, Mahwah, New Jersey: Lawrence Erlbaum Associates, vol. 2, 1999, pp. 563-590.

[8] M. B. Khan. (September 2011). Innamal A'malu Bin Niyat. [Online]. 2. pp. 19. Available: http://www.wpcab.com.bd/english/index.php.

[9] Absolute Purity of Intention. (March 2011). The Odyssey: Be In This World As Though You Were a Stranger or a Traveler. [Online]. Available:

http://thehoopoesodyssey.blogspot.com/2011/03/absolute-purity-of-in tention.html.

[10] Wordofreedom. (July 2012). An Nawawi's 40 Hadith-1. [Online]. Available: http://wordofreedom.wordpress.com/2012/07/19/an-nawawis-40-hadit h-1

[11] L. Askari. (June 2010). Dynamic Attitude Scale - Six Dimensions. [Online]. Available: http://www.scribd.com/share/upload/106778062/1b6n03yse6fqccm71 rlf

[12] K. E. Watkins and V. J. Marsick. (1999). Dimensions of the Learning Organization Questionnaire. [Online]. Available: http://www.partnersforlearning.com/questions2.asp

[13] Y. Yamazaki and D. C. Kayes. "Learning and work satisfaction in Asia: A comparative study of Japanese, Chinese and Malaysian managers," The International Journal of (HRM) Human Resource Management, vol. 21, no. 12, pp. 2271-2289, January 2010.

[14] N. J. Adler and A. Gundersen, International Dimensions of Organizational Behavior, 5th ed., Ohio: Thomson, 2008.

[15] E. T. Hall, Beyond Culture, Anchor Books, December 7, 1976.

[16] L. Dorfman, K. Woodruff, V. Chavez, and L. Wallack. (1997). Youth and violence on local television news in California. American Journal of Public Health. [Online]. 87. pp. 1311-1316. Available: http://www.mediastudiesgroup.org/documents/6HEB-Dorfman.pdf

[17] W. L. Adair and J. M. Brett. (2004). Culture and Negotiation process. The Handbook of Negotiation and Culture. Stanford Business Books. [Online]. ch. $\quad 7 . \quad$ Available: http://www.unice.fr/crookall-cours/iup_cult/_docs/_Gelfand\%202004 $\% 20$ Handbook\%20of\%20Negotiation\%20and\%20Culture.pdf

[18] J. G. Atkinson and P. H. Murrel, "Kolb's experiential learning theory: A meta model for career exploration," Journal of Counseling and Development, vol. 66, no. 8, pp. 374-377, April 1998.

[19] D. A. Kolb, Experiential Learning Experience as a Source of Learning and Development, New Jersey: Prentice Hall, 1984.

[20] D. C. Kayes. (December 2002). Experiential learning and its critics: Preserving the role of experience in management learning and education. Academy of Management Learning and Education. [Online]. 1(2). pp. 137-149. Available: http://www.jstor.org/stable/40214146.

[21] A. Kolb and D. A. Kolb. (2008). Experiential learning theory: A dynamic, holistic approach to management learning. Education and Development Department of Organizational Behavior. Case Western Reserve University Working Paper. [Online]. Available: http://www.learningfromexperience.com/research-library/\#30./http:// www.dancampbell.us/podcast/LTP-9_Kolb_Experiential_Learning.pd f.

[22] A. B. Adams, D. C. Kayes, and D. A. Kolb. (2005). Experiential learning in teams. Simulation and Gaming. [Online]. 36(3). pp. 330-354 http://www.learningfromexperience.com/research-library/\#30.

[23] D. A. Kolb, R. Boyatzis, and C. Mainemelis. (2000). Experiential learning theory: previous research and new directions. in R. J. Sternberg and L. F. Zhang (Eds.). Perspectives on Cognitive Learning, and Thinking Styles. [Online]. Available: http://www.learningfromexperience.com/research-library/\#30.

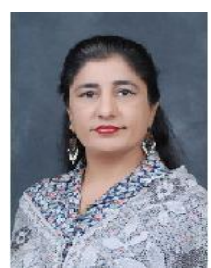

Linah Askari is working as an assistant professor psychology, in the Department of Business Psychology, College of Economics and Social Development, in the Institute of Business Management, Karachi - Pakistan. She holds a Ph.D. in Psychology from the University of Karachi. She is a gold medalist in both M.Sc. Psychology and Post Magistral Diploma in Clinical Psychology from the University of Karachi. She has nine years teaching experience and has been approved as a supervisor for $\mathrm{PhD}$ candidates by Higher Education Commission, Pakistan.

She is the founder director of "Ideal Parents" - A National Trust, to help and train parents to raise successful children. She has been awarded 'Star Laureate' in 2006 from 'Who's Who in Pakistan'.

Dr. Askari is the Inventress of; "Attitudinize Psychotherapy", "Heart the Sixth Sense Organ for Emotions", "Mind the Seventh Sense Organ for Reasoning and Predictability", "Subliminal Persuasion Model 2010", "Pain Management Therapy", "Balanced Workplace Relationship Model", "Psyche' Discipline 2012" and "The Learning Model 2012". She is the Author of "Mother's Dysfunctional Attitude: Is She Responsible for My Emotional State in Adulthood?" published by Lambert Academic Publishing, Germany. She is also the co-editor of "Handbook of Counselling and Psychotherapy in an International Context", published in New York. She is the Patron of MENTOR - The Psychology Club, a student society of Institute of Business Management. 